\title{
Check elastic before jumping
}

Paralysis of the senses, temporarily.

\section{Neal Asher}

Standing before the museum display case, I listened to the cracking of stun rifles outside as CCM - Combined Corporate Military - engaged with the few government troops who could be bothered to fight.

"It's a crappy world," said someone standing nearby.

"Oh really," I said, peering into the case, and remembering my recent hospital visit, which had occurred just a few days before a crowd of some 500,000 drove everyone out of the EU Parliament buildings and then burnt them to the ground...

It felt like I was using the scroll wheel on an old-style computer mouse to work my way down the list of news items, then it felt like I clicked the mouse button to select a news item - National Health Service software having some way to go to catch up with the new interactive displays and virtualities. Of course, I hadn't moved a finger since that moment I decided to flout the EU-wide health-and-safety ban on urban bungee jumping and miscalculated the length of my elastic. My shattered skull and snapped spine had left me unable to do more than blink and swallow. A temporary cortical implant, fitted just before they epoxied my skull back together, provided the sensation of movement from my paralysed limbs and enabled me to use the entertainment system here.

The news item played out in an 'Infinity Deepscreen' holographic display seemingly hanging in mid-air over my bed - this illusion provided by the multicoloured lasers, which were tracking my eyes from my comm unit, at present stuck to the front of my monitor suit. Apparently, Allied Energy was drilling for the carbon dioxide that had been pumped down into the gas and oil fields at the beginning of this century. The hope being that those megatonnes of gas released into the atmosphere will raise temperatures high enough to offset the coming Ice Age by another century. The Green Socialists, still retaining a majority in the European Parliament, were pushing for more stringent controls on energy usage, their contention being that the numerous wind-power projects, having upset the weather patterns of the planet, need to be closed down. I sighed - I could manage that - and was about to move on to the next news item when my consultant interrupted the display.
"How are you today, Joe?"

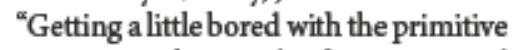
entertainment here and rather concerned that you don't seem to know my name." I didn't actually speak the words, since they were a product of my implant and a voice synthesizer, which made me sound like Humphrey Bogart - the new virtual screen idol.

In the display my consultant peered at his paper notes. ${ }^{\alpha} \mathrm{O}$ kay, Joe, I'll give it to you straight." It must have been some sort of glitch in the system, since I'd commed others in the hospital and apparently this consultant program called all his patients

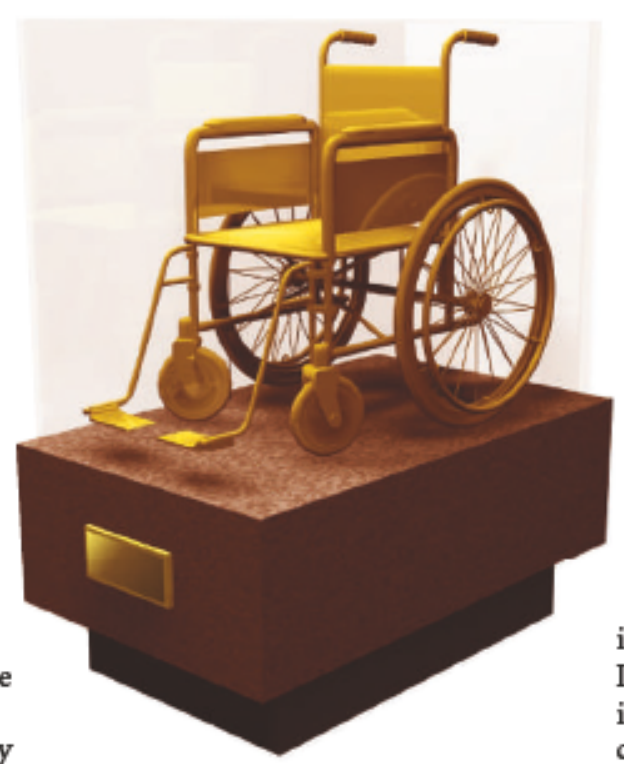

Joe. "You're in

here for the long haul. The new nerve tissue is growing well, but without invasive surgery, it will take some time for the breaks in your vertebrae to knit. You will have to spend a year in a motorized exoskeleton during..."

${ }^{\alpha}$ What about CT nerve-stimulus and keyhole bone welding?" I interrupted.

"NHS funding," he supplied.

"What? Things weren't this bad after I protested the HSE ban on hang-gliding, and that was only two months ago."

"Ah yes, I see," he said, once again peering at my notes. He froze for a moment, which seemed to happen whenever he updated, then continued in a slightly different tone. "I see that then you were a European citizen, but now it appears you are a citizen of Ubermart?

"Yes, I certainly am — I'd rather my taxes went to a more deserving cause." Really, what had finally persuaded me to sign up for corporate citizenship was the last burglary of my apartment. The guy breaking in managed to stab himself with the screwdriver he tried to jemmy the door with and I called him an ambulance. The police arrested me for negligence and then helped the burglar to sue me for damages. Apparently hewas 'disadvantaged,' unable to read or write due to ritalin abuse and dietary cerebral damage. Corporates tend not to suffer the same problems. Corporate police tend to take an old-fashioned approach to policing, usually in CCTV blackspots.

"If you could confirm your Ubermart citizenship number?"

I recited it for him quickly and his image froze again. When he thawed out he said, "Thank you citizen Philips. Do you mind if I call you Derek??

"Of course not, it's my name."

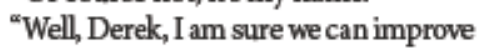
on my previous prognosis. Before we get to that, would you like to enjoy our virtual-reality facilities during your stay?"

"How long will that be?"

"Oh, I think we can have you out of here by this afternoon, Derek.

"That's okay - I'll stick with what I have for the moment. ${ }^{x}$ 'd forgotten all about Ubermart's health plan, which as one of their citizens I could also enjoy.

The rest of the day just seemed to speed past. Actual human nurses came in with a suit hoist, asked me kindly if I was ready while simultaneously instructing my suit to inject a really trippy narcotic. Just before I went under I observed a surgical robot cracking open my monitor suit then poising over me while extending its glittering cutlery.

I awoke amid clean sheets. Walked out of the hospital only an hour later.

The sounds of stun rifles firing seemed to be decreasing.

"You don't agree that it's a crappy world?" asked the guy standing next to me.

"Okay, it's crappy, but it could be worse."

He harrumphed and moved away. I returned my attention to the display case and smilingly inspected the wheelchair resting there, then the dates on the plaque indicating when the first one was invented, and when the last one was used.

Neal Asher is now on his third three-book contract with Macmillan, is translated into nine languages and reckons he's doing okay. His latest book, Polity Agent, will be available at the end of this year, http://freespace.virgin.net/n.asher. 